\title{
Goretity JózseF \\ A Médea és gyermekei az orosz irodalmi hagyomány tükrében
}

Amikor Ljudmila Ulickaja életművével vagy az életmü valamelyik alkotásával kezdünk el foglalkozni, mindig szembe kell néznünk a szerző népszerűségének kérdésével. Kétségtelen ténynek tetszik, hogy Ljudmila Ulickaja a hazájában, Oroszországban hoszszú ideje az egyik legnépszerübb kortárs író: a könyvei nagy példányszámban kelnek el, egy-egy új művének megjelenése különleges eseménynek számít az orosz irodalmi életben, írásai rendszeresen a legjelentősebb orosz irodalmi díjakat nyerik el. Könyveit több tucat idegen nyelvre fordították le, és számtalan nemzetközi irodalmi dijban részesültek. Magyarországon is a legnépszerübb kortárs orosz írónak számít, gyakorlatilag minden jelentős írása olvasható magyarul, könyvbemutatóira, író-olvasó találkozóira több száz fös tömegek kíváncsiak. Ugyanakkor írói pályájának kezdetétől fogva újra és újra előkerülnek mind az oroszországi, mind a magyarországi irodalomkritikában olyan fanyalgó vélemények, amelyek a népszerüséget alacsony művészi értékként értékelik, az Ulickaja-müveket valamely „színvonalas populáris irodalomnak” aposztrofálják. Véleményem szerint az efféle kritikai megnyilvánulások (nem csak az Ulickajaírásokkal kapcsolatban) figyelmen kívül hagyják, hogy az irodalmi értéket nem, vagy nem kizárólagosan tükrözi az eladott példányszám. Ráadásul a kiugró könyvpiaci siker megdönthetetlen érvként hol a komoly irodalmi érték igazolásaként, hol pedig - éppen ellenkezőleg - a müvészi érték hiányaként, a valódi értékek popularizálásaként jelenik meg a kritikai diskurzusokban. Az első esetben, következetes logikával végiggondolva, azt kellene feltételeznünk, hogy napjaink legértékesebb irodalmi művének, mondjuk, a több milliós példányban eladott Harry Pottert kellene tartanunk, a második esetben pedig arra az eredményre kellene jutnunk, hogy az a legértékesebb regény, amelyet maximum egyetlen olvasó olvasott.

Ulickaja népszerűségével, kiváltképp külföldi népszerűségével kapcsolatban gyakran fogalmazódik meg az a vélemény is, hogy nemzetközi ismertségét és elismertségét elsősorban annak köszönheti, hogy írásai valójában nem orosz szellemiségüek: elmaradnak a klasszikusok mélységétől, nem kötődnek az orosz irodalmi hagyományokhoz, nincs bennük semmi nemzeti érték, legfeljebb csak valami ócska klisékből álló „szuvenír” oroszság, amely eleve külföldi „fogyasztásra” készül. Ennek, véli a kritika, egyik bizonyítéka, hogy Ulickaja regényei rossz nyelviséggel, „kilúgozott”, helytelenül használt orosz nyelven vannak megírva. ${ }^{1}$ Tanulmányomban többek között ezekkel a

\footnotetext{
${ }^{1}$ A különböző internetes portálokon végtelen számú bejegyzés terjed Ulickaja és az Ulickaja-írások nem orosz voltával kapcsolatban. E bejegyzéseknek vajmi kevés közük van az objektív irodalomkritikához, sok-
} 
- rosszindulattól sem mentes - vádakkal szemben is szeretném megvédeni a szerzőt, még ha az írónő és könyvei nem is szorulnak egy magyar kritikus védelmére.

A művészi értéktelenség, felszínesség és a „nem eléggé orosz” vádakkal szembeni védelemhez annál is inkább alkalmasnak látszik a Médea és gyermekei címü korai, 1996-ban született regénye, mert a mü címe valóban az orosz kultúrán kívüli kultúrkörre, az antik görög mitológiára utal. A mű a Médeia-mitologéma 20. századi orosz parafrázisának hathat ${ }^{2}$ - első pillantásra akár igazolni látszik az „idegenség” vádját. Tény ugyanakkor az is, hogy az Ulickaja-féle Médeia jelentősen eltér mind az eredeti mitologémától, mind az antik mitologémát feldolgozó, más világirodalmi alkotásokban szereplő Médeia-alakoktól, amelyek általában - ilyen vagy olyan formában - a gyermekgyilkos Médeia alakját mutatják be. Hogy az Ulickaja-regény miként dolgozza fel az antik mítoszt, azt Darab Ágnes alapos tanulmányából megtudhattuk. ${ }^{3}$ Szerinte Ulickaja Médeia-alakjának legföbb különlegessége az, hogy a közismert, „kétarcú” mitológiai alakból nem a sötét lelki erőket Médeiának tulajdonító elbeszélést dolgozza fel, hanem a másik oldalát, a füves asszonyt, a gyógyítót, a „fényes” alakot. Darab Ágnes koncepciójához nincs mit hozzátenni. A jelen tanulmányban mindenekelőtt azt igyekszem bemutatni, hogy az Ulickaja-féle Médeia alak minek köszönhetöen esett át a változáson, milyen kontextusba ágyazódik be, melyek azok az orosz kulturális, irodalmi vonatkozások, reminiszcenciák és allúziók, amelyek a görög eredetit az orosz hagyományokba illeszkedő regényhőssé alakítják. ${ }^{4}$

kal inkább az antiszemita kirohanások tárgykörébe tartoznak, és nem mentesek a trágár szidalmazásoktól sem. A szitkozódók sorába olyan jó nevü orosz költő is beállt, mint Jurij Kublanovszkij. (KubLANovszkiJ, Proscsanyije s Jevropoj Ljudmili Ulickoj, Rosszijszkaja gazeta, 2014/7.) Az irodalomkritika müfajába többékevésbé besorolható írások közül e témakörben lásd még Olga Rizsova írását, aki „szerzői biologizmussal”, a szexualitás naturális ábrázolásához való különös hajlandósággal vádolja Ulickaját, műveit pedig a bulvárirodalom körébe sorolja. (Rizsova, Koitusz Kukockogo, ili Szamaja intelligentnaja domohozjajka, Lityeraturnaja gazeta, 2004/37.) Lev Kuklin Ulickaja műveit „semmiről sem szóló” írásoknak titulálja. (KuKLIN, Kazusz Ulickoj, Nyeva, 2003/7, 177-183.) Lev Danyilkin az Ulickajával készített interjúban azt állítja, hogy Ulickaja regényeinek megvan a pontos képlete: sok szex, sok duma a lelkiismeretről, az akarat szabadságáról, a felelősségérzetről, az örökségről, vagyis nem más, mint latin-amerikai szappanopera a liberális értelmiség számára. (DANYILKIN, Ggye tvoj mungyir, liberal?, Afisa, 2011/290.)

${ }^{2}$ Ulickaja írásaival kapcsolatban gyakran emlegetik az újmitologizmust mint regényeinek egyik alapvető szervező elvét és módszerét. Lásd ezzel kapcsolatban például Szvetlana TYımına, Ritmi vecsnosztyi: Roman Ljudmili Ulickoj Medeja i jejo gyetyi = Russzkaja lityeratura XX veka v zerkale krityiki: Hresztomatyija, szerk. Sz. I. tyimina, M. A. CsernyaK, N. N. KJasto, Szankt-Petyerburg, Academia, 2003, 432-456.

${ }^{3}$ Darab Ágnes, Médeia útjai (L. Ulickaja: Médea és gyermekei), Alföld, 2009/9, 85-93.

${ }^{4}$ Egy orosz kritikus, Konsztantyin TRUNYIN az internetes portálján a Médea és gyermekeiről írott kritikájában azt állítja, hogy a regényhős és az antik mitológiai hős között nincs semmilyen összefüggés, hasonlóság, ezért értelmetlen dolog lenne bármi ilyet is keresni. Kijelentését arra alapozza, hogy Ulickaja bevallása szerint Médea Mendesz a szerző férjének, Andrej Kraszulinnak az egyik rokona, hús-vér, valós, létező ember, akinek nehéz sorsa volt. A kritikus szerint Ulickaja következetlenül, rosszul, töredékesen meséli a rokon hölgy életrajzát, és a regény így nem lesz más, mint életkrónika, amelyet a szerző kommentárjai kísérnek. http://trounin.ru/ulitsky96 (Letöltés ideje: 2017. július 31.) 
Ulickaja narrátora, a regényhős nevének megfelelően, nem győzi hangsúlyozni, hogy Médea Mendesz a Krímben él, déli típusú, és nyilvánvalóan görög felmenőkkel rendelkezik. A déliségről, a görögségről szóló információk vezérmotívumként vonulnak végig a regényen, és létrehoznak egy olyan kulturális hálót, amelyben nem az antik görög, hanem sokkal inkább a keresztény görög, tulajdonképpen a keleti keresztény, a bizánci értékrend (elsősorban erkölcsi értékrend) és magatartásforma érvényesül. Ennek az értékrendnek semmi köze a nyugati, individualista szemléletmódhoz, hiszen Médea magatartását önmaga önkéntelen háttérbe szorításával a közösség (a legtágabb értelemben vett család) szervezése, összetartása vezérli. Ennek alapján egyértelmünek és természetesnek tetszik, hogy Ulickaja az antik görög mitológiai alaknak nem a közismert kegyetlen, hanem a kevésbé ismert „fényes” variánsát emeli ki, mivel ez egyeztethetö össze inkább a keleti keresztény hagyománnyal. A társadalmi életben a szellemi-lelki közösség (a „szobornoszty”) az ideálja, a magánéleti kérdésekben pedig a megbocsátás, illetve a sorssal való megbékélés (a „szmirenyije”) a meghatározó számára. Olyan magatartásforma, erkölcsi értékrend és világszemléleti eszmények ezek, amelyek az orosz kultúra több mint ezeréves történetét határozzák meg, attól kezdve, hogy Vlagyimir fejedelem - a legenda szerint - a különféle vallások „megversenyeztetése" után a bizánci kereszténységet választotta az oroszok számára. Aztán az orosz középkorban, Bizánc bukását követően Filofej metropolita megfogalmazta a „Moszkva - a Harmadik Róma” tételt, amelynek értelmében miután a kereszténység első bástyája, Róma elesett, a kereszténység védőbástyája Bizánc lett, majd Bizánc bukását követöen Moszkvára hárul a kereszténység védelmének feladata, és az Oroszország képviselte kereszténység, a pravoszlávia az egyetlen igaz kereszténység. Még később, a 18. század elején, Szentpétervár megalapítását követően, amikor az új főváros mind az orosz államiság, mind az orosz vallás központjává vált, Szentpétervárt - külsőségek alapján is - Észak Rómájának és Észak Velencéjének kezdték nevezni. Végül, az úgynevezett orosz „ezüstkor” idején, a 20. század elején az orosz kultúrában, különösen az irodalomban nagy szerepet kapott az antik görög és az itáliai kultúra, és ez utóbbi kapcsán Dante kultusza. A századforduló orosz kultúráját és irodalmát kutatva nem véletlenül jutott Szilárd Léna arra a következtetésre, hogy az orosz szimbolizmust lehet és érdemes egyfajta Dante-kódban értelmezni. ${ }^{5}$ Mindezek alapján egyáltalán nem meglepő, hogy az orosz kultúra egyik legkiválóbb kutatója, Dmitrij Lihacsov Az orosz kultúra két ága ${ }^{6}$ címü alapvető tanulmányában azt állítja, hogy az orosz kultúra történetén végigvonuló kelet-nyugat ellentét (tudniillik hová tartozik Oroszország, Európához vagy Ázsiához) mellett két másik pólus - az északi és a déli - feszültsége is számottevő. Az északi pólust a varjág (normann) eredetü államalapítás képviseli, és az erőszakot, a katonai jelleget, a hódítást hordozza magában; a délit, a bizáncit pedig a bölcsesség, a szépségkultusz, a

\footnotetext{
${ }^{5}$ Lásd a monográfia V. fejezetét (Az orosz szimbolizmus Dante-kódja): SzILÁRD Léna, Andrej Belij és az orosz szimbolista regény poétikája, Bp., Széphalom Könyvműhely, 2002, 89-132.

${ }^{6}$ Dmitrij Linacsov, Az orosz kultúra két ága, ford. Goretity József, Bp., Russica Pannonicana, 2010.
} 
közösségi jelleg, a megbékélés jellemzi. Úgy tetszik, a Médea és gyermekeiben hangsúlyozott görögség az orosz kultúrának ezt a déli ágát (is) jelenti.

Más kérdés, hogy mindettől függetlenül ott él a regényben az antik görög mítosz és kultúra is - orosz átértelmezésben. Mi sem bizonyítja ezt jobban, mint a regény cselekményének helyszíne. A regény szövege - bár konkrétan nem hangzik el - egyértelműen meghatározza a helyszínt: a cselekmény a Krímben, még pontosabban egy kis üdülövárosban, Koktebelben játszódik. Földrajzilag valós helyszínről van tehát szó, ugyanakkor bizonyos értelemben fiktívről is, az orosz kultúra és irodalom legendás helyéröl. Koktebel ugyanis fontos szerepet játszott az orosz „ezüstkor” kulturális életében. Köztudott, hogy ez az a krími kisváros, ahol az orosz szimbolisták egyik jelentős alakjának, Makszimilian Volosinnak háza volt, és amelyben - különösen 1917-et követően - az orosz szimbolizmus és posztszimbolizmus jeles képviselői vendégeskedtek, az új, ellenséges proletárkultúrával szemben szellemi központot és magas szintü kulturális életet is létrehozva egyúttal. Volosin az orosz szimbolisták ifjabb nemzedékéhez tartozott, és szoros kapcsolatban állt azzal a fiatal moszkvai értelmiségiekből álló csoportosulással, amely az Argonauták elnevezést kapta, és amelynek célkitüzései közé tartozott, hogy a szimbolisták idősebb nemzedékének (például Konsztantyin Balmontnak) l’art pour l’art müvészeti eszményével szemben létrehozza a „valódi” szimbolizmust, amely a tiszta művészet helyett misztikus-ezoterikus kifejezésmódot alkalmaz. A transzcendencia felé törekvést az Argonauták számára az aranygyapjú keresése jelképezte.

Jellemzö, hogy a csoportosulás szoros kapcsolatban állt a Zolotoje Runo, azaz az Aranygyapjú címü irodalmi-müvészeti folyóirattal. A csoportosulás vezetője az akkor még a pályája elején járó Andrej Belij volt, aki baráti viszonyban állt Makszimilian Volosinnal. Hogy mennyire hasonló esztétikai nézeteket és világnézeti elveket vallottak, bizonyítja, hogy mindketten lelkes hívei voltak a Rudolf Steiner-féle antropozófiának, és 1914-ben (másokkal együtt) mindketten Dornachba utaztak, hogy részt vegyenek az első Goetheanum építésében. Az 1903-ban alakult moszkvai Argonauták köre mindössze néhány évig állt fenn (legkésőbb az évtized végére megszűnt), viszont 1924-ben Szimferopolban, a Tauriszi Egyetemen (ahová akkorra az ország számos pontjáról költöztek át a szovjethatalom elől menekülő professzorok) egyetemi hallgatók egy csoportja létrehozta a Krími Argonauták körét. A meglehetősen bohémnek ható társaság igyekezett fenntartani és folytatni a forradalom előtti kultúrát, ám a művészeti-kulturális események, összejövetelek szervezésén túl egyfajta segítségnyújtást is megvalósítottak a nehéz helyzetbe sodródott értelmiségiek számára. A társasággal kapcsolatba került a Koktebelben élő Volosin is. A Krími Argonauták vezéregyénisége egy bizonyos Marija Izergina volt, aki - miután a kör nem sokáig létezhetett a szovjet viszonyok között - három évtizeddel később, 1956-ban házat épített Koktebelben, amely alkotóházként és menedékhelyként szolgált a szovjet kulturális életből kiszorult művészek és értelmiségiek számára. ${ }^{7}$ Mindezt figyelembe véve arra a következtetésre juthatunk, hogy a

${ }^{7}$ Erről részletesen lásd Natalja MencsinszKajA, Krimszkije „argonavti” XX veka, Moszkva, Kriterion, 2003. 
hangsúlyozottan görög származású Médea házának - ahol a regény szereplői menedékre lelhetnek - mintájául a Médeia-mondakört felidézó két orosz Argonauta csoportosulás vezéregyéniségeinek, Volosinnak és Izerginának koktebeli háza szolgálhatott.

Nyilvánvalónak tetszik azonban, hogy bár a regényben hangsúlyosan szerepel a „görög vonal", ezen kívül számos más nemzetiség képviselője is rendre felbukkan. Menedékre lelnek Médeánál vagy szoros kapcsolatban állnak vele zsidó, tatár, grúz, örmény, litván, koreai és természetesen orosz származású hősök, létrehozva a müben egy sajátos „multikulturális” közeget. Médea háza nemzetiségi hovatartozásra való tekintet nélkül befogad mindenkit, megvalósítva ezzel nemcsak az igen tágan értelmezett rokoni-családi egységet, hanem a népek-nemzetiségek nagy családjának eszményét is. Márpedig, ha az orosz államiság, gyakorlatilag a létrejöttétől kezdve, valamire büszke volt és apellált, az nem volt más, mint éppen a nemzetiségi sokszínűségre alapozott nemzeti egység. Más kérdés persze, hogy ez a történelem folyamán hogyan valósult (vagy inkább nem valósult) meg a gyakorlatban, a 20. század elejétől felerősödött zsidóüldözésektől kezdve a krími tatárok erőszakos kitelepítéséig a sztálini korban. (Éppen erre történik utalás a regényben Ravil Juszupov történetével.) Mindenesetre annyi megállapítható,

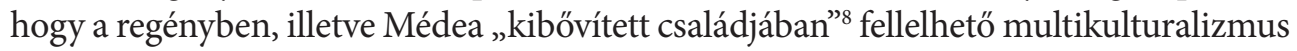
a házat a soknemzetiségü Oroszország metaforájává avatja.

A ház mint Oroszország metaforája talán új megvilágításba helyezheti azt a szembeszökő különbséget is az Ulickaja-féle Médeia alak és az antik görög Médeia között, hogy Ulickaja Médeája nem öli (nem ölheti) meg a gyermekeit, hiszen eleve gyermektelen. Az a család, amelyet maga köré gyüjt és összeköt, „kibővített család”, gyakorlatilag bárki akár egész Oroszország - belefér. Van Andrej Platonovnak, a 20. századi orosz irodalom egyik kiemelkedő alakjának (akinek müvészetét, mellesleg, Ulickaja is nagyra tartja) egy regénye, a Munkagödör, amelynek a ház mint Oroszország metaforája az alapja. A regény szereplöi elhatározzák, hogy felépítik a kommunizmus házát, de az építkezés nem jut túl azon, hogy egyre csak ássák az alaphoz szükséges munkagödröt: minél inkább építkeznek, annál inkább mélyül a gödör. A forradalmi romantikával vagy keserü iróniával (a mü zsenialitása többek között abban rejlik, hogy a kérdés eldönthetetlen) megírt regényben a kommunizmus háza befogadna minden elesettet, rokkantat, apátlan-anyátlan árvát. Az egész számkivetett orosz társadalom egyetlen nagy család lesz, biológiai apa nélkül, ahol az apát a szellemi atya szerepében fellépő Lenin tölti be. Platonov írásait át- meg átszövi az apanélküliség, az árvaság, a meddőség, az élet és halál mezsgyéjén létezés gondolata. Az egyetlen menedéket a nagy közös ház, a társadalom mint család jelenti a hősei számára. Az ember számára pedig ez a közösségi élmény a megváltás - már ha van egyáltalán.

Ulickaja regényhőseinek Médea háza egyfelől zarándokhely, megtisztulást, vezeklést hozó hely, ahová bünökkel teli hétköznapi életükből visszatérhetnek, ahol vigaszra lelhetnek, megbocsátást nyerhetnek. Mi sem fejezi ki jobban ezt a szakrális és profán

${ }^{8}$ Olga Berjozkina terminusa. BerJozkInA, Isszledovanyije isztorii raszsirjonnoj szemji na matyeriale romana L. Ulickoj Medeja i jejo gyetyi. https://www.psyoffice.ru/6060-12-2679.html (Letöltés ideje: 2017. július 31.) 
keverékéből álló állapotot, mint a Platonovhoz illő groteszk kép, amikor is a frissen Médea házába érkezett Grigorij a szükség minden érzete nélkül bevonul a birtok legmagasabb pontján álló deszka budiba, és ott elolvassa a megboldogult Mendesz „használati utasítását”: „Használat után nézz hátra, tiszta-e a lelkiismereted”. ${ }^{9}$ Másfelől olyan hely is, ahol új kísértések csábítanak, új bünök foganhatnak, leginkább a testi vágyak, a testi szenvedélyek nyomán. A regényben a legszemléletesebb példája ennek talán az a holdfényes éjszaka, amelyen az egész életében a testi ügyességéből, testi erejéből és testi vonzerejéből élő Butonov alig néhány percnyi különbséggel magáévá teszi a két unokatestvért, Mását és Nyikát. Igaz, Médea, aki akaratlanul is mindennek tanújává válik, abban a pillanatban meg is bocsátja a két fiatalasszony bünét.

A család, a vér szerinti kötődés, a hűség és a megcsalás, a szerelmi szenvedély tehát egészen más erkölcsi megítélés alá esik, mint a Médeia-mítoszban, elsősorban a korábbiakban már felemlegetett „szmirenyije” fogalma miatt. Ugyanakkor nem arról van szó, hogy a testi szenvedély nem bünként mutatkozna meg Ulickaja müvében. Ennek kibontásához azonban rá kell mutatnunk a Médea és gyermekeinek egy újabb intertextuális vonatkozására. Az Ulickaja-életmü alighanem legszakavatottabb ismerője, Tatyjana Koljagyics az egyik tanulmányában ${ }^{10}$ azt hangsúlyozza, hogy a Médea és gyermekei alapvetően a Dosztojevszkij-féle „bün és bünhődés” problematikáját járja körbe, azt dolgozza fel a 20. század végének szempontjai alapján. Koljagyics a regény cselekményét úgy értékeli, mint a bünként felfogott testi szenvedélynek végtelenített, sorsszerüen, büntetésként újra és újra felbukkanó variációit. Ulickaja regényében, bármennyire is összekuszálódnak az események és a szereplők életútjának szálai, jól kivehetők bizonyos párba állított, teljesen ellentétesnek látszó, vagy nagyon is hasonló, egymás tükörképének látszó sorsok. Ilyen például Médea és testvére, Szandrocska sorsa, aztán Szandrocskának és a Médea férjétől, Szamuiltól született törvénytelen lányának, Nyikának a sorsa, aztán Nyikának és unokatestvérének, Másának a sorsa, akiknek ugyanazzal a férfival (Butonovval) van házasságon kívüli viszonyuk, végül Médea bátyjának, Fjodornak és apjának a sorsa, akinek ugyanúgy házasságon kívüli, törvénytelen gyermeke (Surik) születik, mint Szamuilnak. A hősök ilyetén párba állításában könnyedén felismerhetjük a Dosztojevszkij-féle hasonmásságot, a nagy klasszikus egyik jellegzetes alakteremtő elvét, ráadásul a bün problémájával összekapcsolva. Ulickaja ugyanakkor át is értelmezi a hasonmás-problémát, továbbgondolja azt, amikor a narrátorral ezt mondatja: „A párosság híres törvénye, ami csak az ugyanazon események ismétlődését hirdető általánosabb törvény alpontja [...]" (257.) Vagyis a hasonmásság Ulickajánál arra szolgál, hogy az események és sorsok végtelen ismétlődését érzékeltesse. Elkövettetett az ősbün, a házasságtörés, még a mitológiai időkben, elkövettetett Médea életében, Médeával szemben, és azóta ismétlődik, a végtelenségig. Mindazok számára pedig, akik ebben részt vesznek, egyszerre bün is, a

\footnotetext{
${ }^{9}$ Ljudmila Ulickaja, Médea és gyermekei, ford. V. Gilbert Edit, Goretity József, Bp., Magvető, 2003, 17. (A további regényidézetek oldalszámait a citátumok után, zárójelben közlöm. - G. J.)

${ }^{10}$ Tatyjana Koljagyics, L. Je. Ulickaja (1943) = T. M. K., Russzkaja proza rubezsa XX-XXI vekov, Moszkva, Flinta-Nauka, 2011, 471-491.
} 
bűn ismétlődése is, de egyúttal szenvedés, következésképpen vezeklés is, a megbocsátás és a megváltás lehetösége is. Bün és bünhődés, bünelkövetés, vezeklés és megbocsátás így, ebben a bonyolult és ambivalens formában bontakozik ki Ulickaja regényében. És éppen ettől lesz olyannyira emberi. Azt hiszem, ezt nevezik müvészi erőnek.

Az eddig elmondottak során - ha csak látensen is - többször érintettük a család problémáját. Ismeretes, hogy a klasszikus orosz irodalom gyakran dolgoz fel családtörténetet, Osztrovszkij sorsszerűséget sugalló családi drámáitól kezdve Turgenyev nemesi családok életformáját feldolgozó regényein keresztül Dosztojevszkij apagyilkossággal végződő családregényén, Szaltikov-Scsedrin leépülést bemutató családi históriáján, Leszkov szenvedélyes vágytól fütött házasságtörési történetén át Csehov reménytelenséget, kilátástalanságot sugalló családtörténetéig. És persze ott van az orosz klasszikus regényirodalom legjelesebb családregénye, az Anna Karenina is. Bármelyik szerzőt és müvét is nézzük azonban, egyikben sem látunk családi boldogságot. Tolsztoj említett regénye ebből a szempontból egészen megdöbbentő: bár számtalan család életébe enged bepillantást, egyetlen jól müködő házasságot sem találunk közöttük, még a regény végére látszólag családi boldogságban élő Kitty és Levin házassága sem hoz boldogságot a házastársaknak. Erre utal a regény elhíresült nyitó mondata is: „A boldog családok mind hasonlók egymáshoz, minden boldogtalan család a maga módján az." ${ }^{11}$ (Az egyetlen, érdek nélküli szereteten és kölcsönös megbecsülésen alapuló férfinő kapcsolat Nyikolajnak, Levin korábban kicsapongó, önpusztító életet élt és halálos beteg bátyjának és élettársának, a bordélyból kihozott egykori prostituáltnak közös életében fedezhető fel.) Az orosz klasszikus irodalom családregényei, köztük Tolsztojé is, a felbomló családok történetét, a felbomlás folyamatát írják meg. Az Anna Karenina ezt szerkezeti szempontból is megjeleníti: a regény cselekménye két, jól érzékelhetően elkülöníthető szálra (az Anna-Vronszkij és a Kitty-Levin szálra) bomlik szét, és ezt a szétesőnek látszó szerkezetet Tolsztoj motivikus hálóval köti össze. Ulickaja regényének cselekményvezetése esélyt sem ad arra, hogy családi összetartást, összetartozást jelenítsen meg. Klasszikus értelemben családról sincs már szó: a fő cselekményszál egy olyan család történetéröl szól, amelynek férfi tagja már nem él, egyébként pedig a házaspár gyermektelen. Minden más családról kiderül, hogy - leginkább a házastársi hüség hiánya miatt - felbomlóban van, vagy fel is bomlott. Még akkor is igaz ez, ha a nyaralás idejére a családok, újabb összetételben, össze-vissza keveredő féltestvéri és egyéb elképesztő rokoni kapcsolatokban összetalálkoznak, együtt vannak, látszólagos egységet alkotnak. Csakhogy az ilyen közös nyaralások újabb és újabb alkalmakat szolgáltatnak a családokon, szállóvendégeken és szomszédokon végbemenő újabb „cserebomlásokhoz" (a goethei értelemben), vagyis ahhoz, hogy újabb felbomlások és ideiglenes egyesülések menjenek végbe. Ezt az egész, dinamikusan felbomló-egyesülő folyamatot és "kibővített családot” egyetlen ember, Médea igyekszik összetartani, aki viszont nem irányítója ennek a folyamatnak, legfeljebb megbocsátó szemlélője, de leginkább

${ }^{11}$ Lev TolsztoJ, Anna Karenina, ford. NÉMETh László, Bp., Európa, 1974, I, 5. 
akaratlan résztvevője, tekintettel a nővére és a férje között végbement házasságtörésre. Nincs esély sem valamely hajdanvolt egység feltámasztására, sem valamely új egység megteremtésére. Leginkább az ősi bün elkövetése és folytonos újraismétlése miatt.

Ez a széthullás formai szempontból is kifejezést nyer. A kritika is, de maga az írónő is állandóan hangsúlyozza, hogy Ulickaja kedvelt műfaja a kispróza: a novella, az elbeszélés. Bármilyen furcsa is, a Médea és gyermekei müfaját sem regényként, hanem elbeszélésként határozza meg a szerző. Másfelől, ha a Médea cselekményvezetését és struktúráját nézzük, láthatjuk, hogy több, egy-egy szereplő élettörténetét elbeszélő történetből, lényegében elbeszélésből áll. Azt is mondhatnánk, hogy a könyv több különálló, a helyét akár önállóan is megálló elbeszélés összeillesztése. Mindezen túl az egyes elbeszélések sem teljesek, sokkal inkább az elliptikus szerkesztés jellemző rájuk, fragmentáltak. E szempontból a klasszikus orosz irodalomból Csehov elbeszéléseit idézik, leginkább azokat, amelyeket Genisz és Vajl „mikroregényeknek” nevezett. ${ }^{12}$ Olyan elbeszélések ezek, mint például az Unalmas történet, a Jonics vagy A menyasszony, amelyek igényt tartanak a regény müfajára, és ennek megfelelően egész élettörténet elbeszélésére törekszenek, terjedelmükben viszont nem többek egy novellánál. Az ilyen elbeszélések nem tartják be a klasszikus novellák cselekményvezetésének alapvető szabályát, hogy tudniillik a föhős életének fordulópontját mutatják be, hanem színre viszik az egész élettörténetet. Kérdés persze, hogy a Médea fragmentált elbeszélésekből összeállított cselekménye tud-e teljes egésszé összeállni. Nyilvánvalóan nem, tehát a mű egésze is fragmentált lesz, benne is érvényesül az elliptikus szerkesztés. Genisz és Vajl terminusával élve: mikroregény lesz. Az egész történetet nem képes összetartani más, mint a narrátor, aki - voluntarista eszközökkel - a sorsokat bölcs, megbocsátó mosollyal szemléli, és egy krónikás szenvtelenségével meséli el a történéseket. Nem értékel, nem fogalmaz meg erkölcsi ítéleteket, vállalja a történetek, magatartások, vélemények közötti ellentmondásokat, ennek következtében saját elbeszélésének önellentmondásait is. Pontosan úgy, mint a Csehov-elbeszélések.

A fentiek remélhetőleg meggyőzőek voltak abban a tekintetben, hogy Ljudmila Ulickaja művei, túl azon, hogy szoros kapcsolatban állnak az európai (és nem európai) kultúrával - a Médea és gyermekei esetében például az antik görög mitológiával -, mélyen beágyazódnak az orosz kultúrába és irodalomba. Az Ulickaja-írások számtalan, az orosz kultúrára tett utalással, reminiszcenciával dolgoznak, intertextuális viszonyba lépnek a klasszikus szövegekkel, ennek következtében komoly előismereteket követelnek az értelmezéskor, vagy intellektuális játékra, ha úgy tetszik, közös alkotásra hívnak fel. Ebből a távlatból szemlélve Ulickaja írásai posztmodern szövegalkotási eljárással születnek. Ugyanakkor Ulickaja gyakran dolgoz fel valós élettörténeteket, valós

\footnotetext{
${ }^{12}$ Pjotr VAJL, Alekszandr Genisz, Édes anyanyelv, ford. GoRetity József, Bp., Európa, 1998, 267-279. (A regényíró útja címü fejezet.)
} 
személyek életrajzát, önéletrajzi elemeket, helyenként létező dokumentumokat (mint a Daniel Stejn, tolmács és a Jákob lajtorjája esetében), a történetei valóságosak vagy valóságosnak látszók, életszerủek. A kritika - hol lesajnálóan, hol dicsérően - megegyezni látszik abban, hogy Ulickaja elbeszélői módszere a kortárs irodalomban az egyik leghagyományosabbnak mondható: a leginkább követi a 19. századi orosz realista elbeszélői módot, és a leginkább köthető a klasszikus orosz irodalmi tradícióhoz. ${ }^{13}$ Ha megnézzük, hogy Ulickaja irodalmi népszerüségének kibontakozása mikorra tehetö, láthatjuk, hogy az 1990-es évek második felére esik (első írása, a Szonyecska 1993-ban jelent meg, hamarabb Franciaországban, mint Oroszországban, a következő regénye, a Médea és gyermekei 1996-ban, az első komoly hazai elismerést, az orosz Booker-díjat a Kukockij eseteiért 2002-ben kapta). Vagyis nagyjából akkorra, amikor a kortárs orosz irodalomban elindult az első, a posztmodern ellenében fellépő „újrealista” hullám, és ezért azt is mondhatjuk, hogy az Ulickaja-művek - akarva-akaratlanul - ennek a hullámnak is a részévé váltak. És ha visszatérünk a tanulmány elején felvetett népszerüség kérdéséhez, akkor bizton állíthatjuk: Ulickaja prózájának népszerüsége elsősorban attól függ, illetve annak köszönhető, hogy össze tudja egyeztetni a klasszikus elbeszélői hagyományokat a posztmodern szövegalkotás eredményeivel. Vagyis, úgy tud intellektuális játékra, idézeteket, utalásokat kereső detektívténykedésre meghívni, hogy közben nem puszta szövegkonstrukciókat, hanem a valós élet problémáival, a mindennapi élet jelenségeivel foglalkozó történeteket kínál az olvasónak.

\section{JÓZSEF GORETITY}

\section{Medea and Her Children in View of Russian Literary Tradition}

The article approaches Lyudmila Ulitskaya's Medea and Her Children from the Ancient Greek myth of Medea. The argument starts from the fact that despite the novel's title, the text shows significant deviation from the story of the original myth. Likewise, the possible reasons for the remarkable differences between the Ancient Greek Medea figure and Ulitskaya's eponymous heroine is the subject of investigation. It is argued that the differences are due to Ulitskaya's distinct reliance on classical Russian literature besides the myth in creating her protagonist. The writer establishes intertextual links between her own novel and some outstanding works of Russian literature. As a result of such reminiscences and allusions, Ulitskaya's heroine represents the moral values and an attitude to life much more typical of classical Russian literature than Antiquity. The article's author concludes by highlighting that the success of Ulitskaya's novels can be attributed to the writer's excellence in combining postmodern literary techniques with the principles of "new realism" - a tendency that follows classical Russian literary traditions.

\footnotetext{
${ }^{13}$ Lásd például Valentyin Korovin, Isztorija russzkoj lityeraturi XX - nacsala XXI veka. Csaszty III, Moszkva, Vladosz, 2014, 240; Naum Lejderman, Mark Lipoveckij, Russzkaja lityeratura XX veka. Tom 2, Moszkva, Akagyemija, 2013, 522.
} 